\title{
Phase Equilibria in the Ag-Ni-Sn System: Isothermal Sections
}

\author{
CLEMENS SCHMETTERER, ${ }^{1}$ HANS FLANDORFER, ${ }^{1,2}$ \\ KLAUS W. RICHTER, ${ }^{1}$ and HERBERT IPSER ${ }^{1}$ \\ 1.-Department of Inorganic Chemistry/Materials Chemistry, University of Vienna, Waehring- \\ erstr. 42, Vienna 1090, Austria. 2.—e-mail: hans.flandorfer@univie.ac.at
}

\begin{abstract}
The ternary system Ag-Ni-Sn is one of the constituents of the quaternary system Ag-Cu-Ni-Sn, which is of interest for the investigation of the interactions of Ag-Cu-Sn solder alloys with $\mathrm{Ni}$ as a substrate. Until now, only limited research has been done on the Ag-Ni-Sn system, especially in the (Ag,Ni)-rich part, most probably due to experimental difficulties caused by the monotectic reaction in the $\mathrm{Ag}-\mathrm{Ni}$ binary system, which extends far into the ternary. In the present work a comprehensive study of the phase equilibria in four isothermal sections of the Ag-Ni-Sn system at $200,450,700$, and $1050^{\circ} \mathrm{C}$ was carried out employing X-ray diffraction (XRD), metallography, and electron probe microanalysis (EPMA). No evidence for the existence of a ternary phase was obtained, and, in most cases, ternary solubilities of the binary phases were found to be insignificant. The liquid miscibility gap at high temperatures caused a number of serious experimental problems during sample preparation.
\end{abstract}

Key words: Lead-free soldering, phase diagram, Ag-Ni-Sn, phase equilibria, isothermal section

\section{INTRODUCTION}

Within the efforts to replace the conventional Sn$\mathrm{Pb}$ solders by more environmentally friendly alloys, knowledge of the quaternary Ag-Cu-Ni-Sn system is necessary to understand interlayer formation between Ag-Cu-Sn solders (the current industry favorite) and $\mathrm{Ni}$ as a substrate material. Furthermore, Ag-Ni-Sn alloys themselves are becoming increasingly popular as solder materials. The characteristics of such an alloy system are clearly summarized by the phase diagram. Higher order systems, however, rely on investigations of their constituent systems. While in the case of $\mathrm{Ag}-\mathrm{Cu}-\mathrm{Ni}$ $\mathrm{Sn}$, information is available for most of its binary and ternary constituents, only little information is available for the Ag-Ni-Sn system. The goal of the work presented here was a comprehensive study of this system, and, as a first part, details of four isothermal sections are reported in this publication (isopleths, liquidus surface and reaction scheme will be the subject of a separate publication ${ }^{1}$ ). Although

(Received February 20, 2007; accepted May 30, 2007; published online September 25, 2007) isothermal sections at higher temperature are of no immediate relevance to lead-free soldering, they still have to be well established if we want to be able to extrapolate to lower temperature, where experimental work is complicated by the slow diffusion rate usually encountered in the solid state. In addition, they are of importance for any attempts to optimize the alloy system by means of the calculation of phase diagrams (CALPHAD) method.

\section{LITERATURE REVIEW}

\section{The Systems Ag-Ni and Ag-Sn}

In this work the binary system Ag-Ni was accepted as established by Singleton and Nash, ${ }^{2,3}$ as the investigation of three samples in this system did not show relevant differences from those in the literature. Information on the liquid miscibility gap is available from Colinet and Pasturel, ${ }^{4}$ who suggested a critical point at about $4000^{\circ} \mathrm{C}$ based on first principles calculations.

The phase equilibria in the Ag-Sn system were taken from Karakaya and Thompson., 


\section{The System Ni-Sn}

The most recent experimental investigation of this system was done by Schmetterer et al. ${ }^{6}$ Their version of the system differs considerably from the last assessment by Nash and $\mathrm{Nash}^{3,7}$ and from two calculated versions of the phase diagram by Ghosh ${ }^{8}$ and Liu et al. ${ }^{9}$ A detailed account of all changes in this system can be found in Schmetterer et al., ${ }^{6}$ so only a short overview is given here.

According to the recent experiments, the transition from the $\mathrm{Ni}_{3} \mathrm{Sn}$ low temperature phase $\left(\mathrm{Ni}_{3} \mathrm{Sn} \mathrm{LT}\right)$ to its high temperature modification $\left(\mathrm{Ni}_{3} \mathrm{Sn} \mathrm{HT}\right)$ comprises a eutectoid and a peritectoid reaction in good agreement with earlier results of Havlicek. ${ }^{10}$ The determined reaction temperatures of 948 and $911^{\circ} \mathrm{C}$, respectively, are in contradiction to most values given in the existing literature, but they are consistent with the early evaluation by Mikulas and Thomassen ${ }^{11}$ and Havlicek. ${ }^{10}$ The $\mathrm{Ni}_{3} \mathrm{Sn}$ LT phase has a narrow homogeneity range of about 0.5 at.\%, whereas the homogeneity range of the HT phase widens at higher temperature. This phase was found to have a cubic $\mathrm{BiF}_{3}$-type structure, as already mentioned earlier by Schubert et al. ${ }^{12} \mathrm{An}$ orthorhombic phase, also suggested for the $\mathrm{Ni}_{3} \mathrm{Sn}$ HT phase, was confirmed to be metastable, formed by martensitic reaction at high quenching rates.

The region around $\mathrm{Ni}_{3} \mathrm{Sn}_{2}$ is far more complicated than previously reported. Besides an NiAs-type $\mathrm{Ni}_{3} \mathrm{Sn}_{2}$ HT phase there are three corresponding orthorhombic LT phases, two of which have incommensurate structures. Detailed crystal structure analyses in this region were performed by Leineweber et al. ${ }^{13-16}$ The transition between the three LT phases and the HT phase is of first order, consisting of two eutectoid and two peritectoid reactions.

The homogeneity range of the $\mathrm{Ni}_{3} \mathrm{Sn}_{4}$ phase extends from 53 to 57 at.\% Sn. In the vicinity of this latter compound several other phases have been reported in the literature, ${ }^{10,17-22}$ which could not be confirmed in the most recent work ${ }^{7}$ and are therefore not included in the phase diagram (Fig. 1).

\section{The System Ag-Ni-Sn}

Literature information on the ternary Ag-Ni-Sn system is rather scarce. Ghosh ${ }^{23}$ presented a calculated isothermal section at $230^{\circ} \mathrm{C}$ among many other systems, but, unfortunately, did not give a detailed description. Hsu and $\mathrm{Chen}^{24}$ presented details of an isothermal section at $240^{\circ} \mathrm{C}$, which was based on both experimental work and calculation; no ternary compound was detected. Later, Chen et al. ${ }^{25}$ also suggested a liquidus projection, which was derived from an investigation of the primary crystallization of a total of 73 samples. Unfortunately, only a few samples were studied by thermal analysis, so only limited quantitative information is available. Apparently, owing to experimental difficulties, Chen and his co-workers made no effort to investigate liquidus temperatures on the $(\mathrm{Ag}, \mathrm{Ni})$

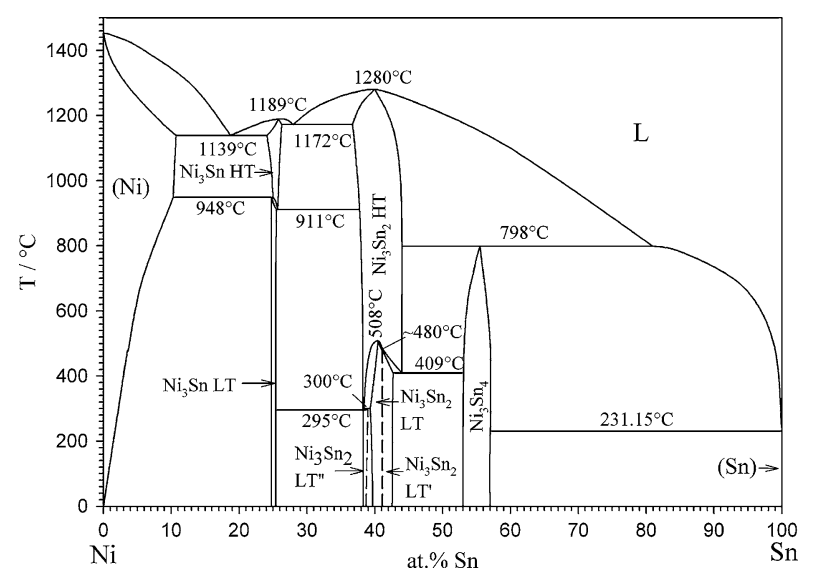

Fig. 1. Ni-Sn phase diagram. ${ }^{6}$

side, so this part of the liquidus surface is only a rough estimate.

Very recently, Ipser et al. ${ }^{26}$ presented preliminary suggestions for the isothermal section at $450^{\circ} \mathrm{C}$ and for the liquidus projection. While being similar to the version of Chen et al. ${ }^{25}$ in the basic outline, there are considerable differences in many details.

All binary phases in the Ag-Ni-Sn system and its constituent systems are given in Table I, while Table II summarizes the invariant ternary reactions discovered in this system so far, according to Chen et al. ${ }^{25}$ and Ipser et al. ${ }^{26}$

\section{EXPERIMENTAL SECTION}

Ag-Ni-Sn alloys were prepared from Ag pellets (99.99\%, Ögussa, Austria), Ni wire (grade 1, Speciality Products, Johnson Matthey, Materials Technology, Royston, U.K.), Ni powder (99.995\% Koch Light Laboratories, Colnbrook, Bucks., U.K.) or Ni sheet (99.99\%, Advent Research Materials Ltd., Eynsham, Oxford, U.K.) and Sn rods (99.9985\%, Tin Rod Puratronic, Alfa Aesar, Johnson Matthey, Karlsruhe, Germany) or Sn ingots (99.999\% Metal Basis, Ventron Alfa Products, Beverly, Mass., USA). Before alloying, we cleaned the Ag pellets by heating them to $600^{\circ} \mathrm{C}$ in a carbon crucible for $10 \mathrm{~min}$.

Calculated amounts of the pure metals were weighed, usually to a total mass of 1-2 g. Various methods had to be employed for alloying because of the special characteristics of this system. Simple arc melting could only be used in those areas of the system that were not affected by liquid demixing extending from the binary $\mathrm{Ag}-\mathrm{Ni}$ monotectic reaction into the ternary. Early attempts to employ the arc furnace in the $(\mathrm{Ag}, \mathrm{Ni})$-rich region were not successful, as the liquid macroscopically decomposed into a Ag-rich and a Ni-rich phase, respectively (Fig. 2). Furthermore, samples in this region seemed to have a particularly high vapor pressure, i.e., high weight losses (up to $3 \%$ of the initial mass) were observed during arc melting and also during thermal analysis. 
Table I. Crystallographic Data of Phases in Constituent Binary Systems According to the Literature ${ }^{2,3,5,6}$

\begin{tabular}{|c|c|c|c|c|c|}
\hline Phase & $\begin{array}{l}\text { Composition } \\
\text { (at.\% Ag) }\end{array}$ & $\begin{array}{l}\text { Pearson } \\
\text { Symbol }\end{array}$ & $\begin{array}{l}\text { Space } \\
\text { Group }\end{array}$ & $\begin{array}{l}\text { Strukturbericht } \\
\text { Designation }\end{array}$ & Prototype \\
\hline \multicolumn{6}{|l|}{$A g-N i$} \\
\hline$(\mathrm{Ni})$ & 0 to 1 & $c F 4$ & $\mathrm{Fm} \overline{3} \mathrm{~m}$ & $\mathrm{~A} 1$ & $\mathrm{Cu}$ \\
\hline (Ag) & 99.8 to 100 & $c F 4$ & $\mathrm{Fm} \overline{3} \mathrm{~m}$ & $\mathrm{~A} 1$ & $\mathrm{Cu}$ \\
\hline \multicolumn{6}{|l|}{$\mathrm{Ag}-\mathrm{Sn}$} \\
\hline$(\mathrm{Ag})$ & 0 to 11.5 & $c F 4$ & $\mathrm{Fm} \overline{3} \mathrm{~m}$ & $\mathrm{~A} 1$ & $\mathrm{Cu}$ \\
\hline$\zeta-\mathrm{Ag}_{4} \mathrm{Sn}$ & 11.8 to 22.85 & $h P 2$ & $P 6_{3} / m m c$ & A3 & $\mathrm{Mg}$ \\
\hline$\varepsilon-\mathrm{Ag}_{3} \mathrm{Sn}$ & 23.7 to 25 & $o P 8$ & Pmmn & $\mathrm{D} 0_{\alpha}$ & $\beta \mathrm{Cu}_{3} \mathrm{Ti}$ \\
\hline$(\beta \mathrm{Sn})$ & 99.91 to 100 & $t I 4$ & $I 4_{1} /$ amd & A5 & $\beta \mathrm{Sn}$ \\
\hline$(\alpha \mathrm{Sn})$ & 100 & $c F 8$ & $F d 3 \mathrm{~m}$ & $\mathrm{~A} 4$ & $\alpha \mathrm{Sn}$ \\
\hline \multicolumn{6}{|l|}{$N i-S n$} \\
\hline$(\mathrm{Ni})$ & 0 to 10.7 & $c F 4$ & $\mathrm{Fm} \overline{3} \mathrm{~m}$ & $\mathrm{~A} 1$ & $\mathrm{Cu}$ \\
\hline $\mathrm{Ni}_{3} \mathrm{Sn} \mathrm{HT}$ & 24.1 to 26.3 & $c F 16$ & $\mathrm{Fm} \overline{3} \mathrm{~m}$ & D03 & $\mathrm{BiF}_{3}$ \\
\hline $\mathrm{Ni}_{3} \mathrm{Sn} \mathrm{LT}$ & 24.8 to 25.5 & $h P 8$ & $\mathrm{~Pb}_{3} / \mathrm{mmc}$ & D019 & $\mathrm{Ni}_{3} \mathrm{Sn}$ \\
\hline $\mathrm{Ni}_{3} \mathrm{Sn}_{2} \mathrm{HT}$ & 36.7 to 44.0 & $h P 6$ & $\mathrm{~Pb}_{3} / \mathrm{mmc}$ & & $\mathrm{InNi}_{2}$ \\
\hline $\mathrm{Ni}_{3} \mathrm{Sn}_{2} \mathrm{LT}^{\prime \prime}$ & $\sim 38.3$ to $\sim 39$ & & & & \\
\hline $\mathrm{Ni}_{3} \mathrm{Sn}_{2} \mathrm{LT}$ & 39.3 to 41.1 & $o P 20$ & Pnma & & $\mathrm{Ni}_{3} \mathrm{Sn}_{2}$ \\
\hline $\mathrm{Ni}_{3} \mathrm{Sn}_{2} \mathrm{LT}^{\prime}$ & 41.25 to 44.0 & & & & \\
\hline $\mathrm{Ni}_{3} \mathrm{Sn}_{4}$ & 53.0 to 57.0 & $m C 14$ & $C 2 / m$ & & $\mathrm{Ni}_{3} \mathrm{Sn}_{4}$ \\
\hline$(\alpha \mathrm{Sn})$ & $\sim 100$ & $t I 4$ & $I 4_{1} /$ amd & A5 & $\alpha \mathrm{Sn}$ \\
\hline$(\beta \mathrm{Sn})$ & $\sim 100$ & $c F 8$ & $F d 3 m$ & A4 & $\beta \mathrm{Sn}$ \\
\hline \multicolumn{6}{|l|}{ Metastable phases } \\
\hline $\mathrm{Ni}_{3} \mathrm{Sn}$ martensite & & $o P 8$ & Pmmn & $\mathrm{D} 0_{\alpha}$ & $\beta \mathrm{Cu}_{3} \mathrm{Ti}$ \\
\hline
\end{tabular}

Table II. Invariant Reactions in the Ag-Ni-Sn System According to the Literature ${ }^{25,26}$

\begin{tabular}{|c|c|c|c|}
\hline \multirow[b]{2}{*}{ Reaction } & \multirow[b]{2}{*}{ Type } & \multicolumn{2}{|c|}{ Temperature $\left({ }^{\circ} \mathrm{C}\right)$} \\
\hline & & Chen et al. ${ }^{25}$ & Ipser et al. ${ }^{26}$ \\
\hline $\mathrm{L} \Rightarrow(\mathrm{Sn})+\mathrm{Ni}_{3} \mathrm{Sn}_{4}+\mathrm{Ag}_{3} \mathrm{Sn}$ & E1 (I) & 219 & 220 \\
\hline $\mathrm{L}+\mathrm{Ag}_{4} \mathrm{Sn} \Rightarrow \mathrm{Ni}_{3} \mathrm{Sn}_{4}+\mathrm{Ag}_{3} \mathrm{Sn}$ & U1 (II) & 488 & 485 \\
\hline $\mathrm{L}+\mathrm{Ni}_{3} \mathrm{Sn}_{2} \Rightarrow \mathrm{Ag}_{4} \mathrm{Sn}+\mathrm{Ni}_{3} \mathrm{Sn}_{4}$ & U2 (II) & 516.5 & 570 \\
\hline $\mathrm{L}+(\mathrm{Ag}) \Rightarrow \mathrm{Ag}_{4} \mathrm{Sn}+\mathrm{Ni}_{3} \mathrm{Sn}_{2} \mathrm{HT}$ & U3 (II) & - & 725 \\
\hline $\mathrm{L} 2+\mathrm{Ni}_{3} \mathrm{Sn} \mathrm{HT} \Rightarrow \mathrm{Ni}_{3} \mathrm{Sn}_{2} \mathrm{HT}+(\mathrm{Ag})$ & $\mathrm{U} 4$ & - & Unknown \\
\hline $\mathrm{L} 2+(\mathrm{Ni}) \Rightarrow \mathrm{Ni}_{3} \mathrm{Sn} \mathrm{HT}+(\mathrm{Ag})$ & U5 & - & Unknown \\
\hline $\mathrm{L} 1 \Rightarrow \mathrm{L} 2+\mathrm{Ni}_{3} \mathrm{Sn} \mathrm{HT}+\mathrm{Ni}_{3} \mathrm{Sn}_{2} \mathrm{HT}$ & $\mathrm{E} 2$ & - & 1130 \\
\hline $\mathrm{L} 1+(\mathrm{Ni}) \Rightarrow \mathrm{L} 2+\mathrm{Ni}_{3} \mathrm{Sn} \mathrm{HT}$ & $\mathrm{U} 6$ & - & $\sim 1,135$ \\
\hline Critical Point & $\mathrm{C} 1$ & - & $1130<\mathrm{T}<1270$ \\
\hline
\end{tabular}

Therefore, during sample preparation in the $(\mathrm{Ag}, \mathrm{Ni})$-rich part we had to avoid heating the sample into the liquid range. Alloying was done with powders of $\mathrm{Ni}_{3} \mathrm{Sn}, \mathrm{Ag}_{3} \mathrm{Sn}$, and $\mathrm{Ni}$ as starting materials. The binary compounds were prepared by arc melting, whereas the Ni powder was a commercial product (see above). Correct amounts of these starting materials were weighed, thoroughly mixed, and pressed into pellets. Ternary alloys were then produced by reactive sintering in evacuated quartz ampules. For equilibration, especially at lower temperatures, the samples were repeatedly powdered, pressed, and annealed again (2-3 weeks each time) to enhance homogenization.

After alloying, all samples were sealed in evacuated quartz glass tubes and annealed at various temperatures followed by quenching in cold water.
The particular procedures of sample preparation and heat treatment are given in Table III; annealing times varied according to the annealing temperature with regard to the melting range of the respective samples.

Powder XRD data at room temperature were, in most cases, obtained in a Guinier Huber film camera (Huber GmbH, Rimsting, Germany) on a Siemens Kristalloflex ERL 1000 generator (Siemens AG, Berlin, Germany) with $\mathrm{Cu} K_{\alpha 1}$ radiation. High purity Si powder mixed with the samples was used as an internal standard; exposure times were between 5 and $10 \mathrm{~h}$. Identification of the different phases was done by comparison of the experimental powder patterns with theoretical diffraction patterns, using the program 'LAZY PULVERIX' of the package 'STRUKTUR'. ${ }^{27}$ A number of samples were 


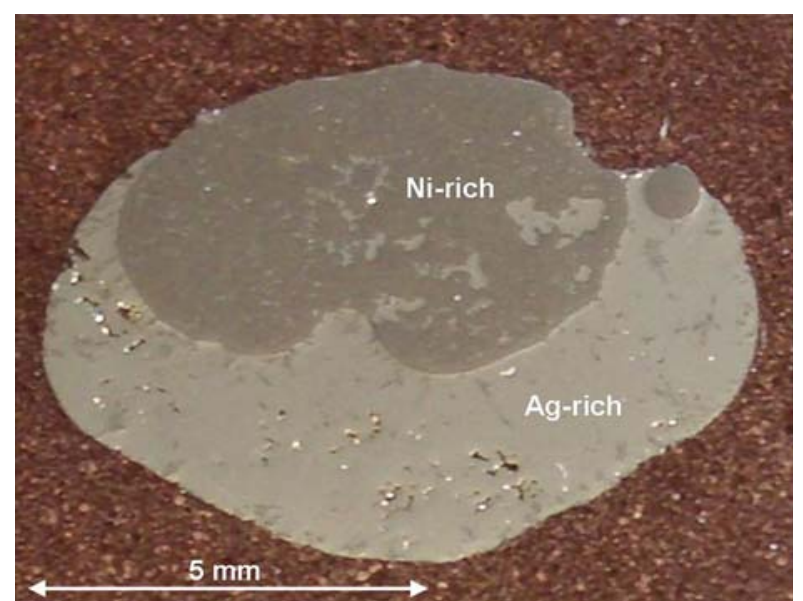

Fig. 2. Ag-Ni-Sn sample showing the effect of the liquid miscibility gap. Demixing of the liquid had occurred during arc melting. The sample is inhomogeneous and not in equilibrium.

investigated using an Image Plate Guinier Camera (Huber $\mathrm{GmbH}$ ), and the patterns were analyzed using the 'Topas 3' software (Bruker AXS, Karlsruhe, Germany). Crystal structure data were taken from Pearson's Handbook of Intermetallic Phases $^{28}$ or from Leineweber et al. ${ }^{13-16}$

Samples to be examined by optical microscope and scanning electron microscope (SEM) techniques were embedded in a mixture of 1:2 volume parts of $\mathrm{Cu}$ powder and Resinar F (Wirtz/Buehler, Düsseldorf, Germany). After embedding, we ground the samples with $\mathrm{SiC}$ discs with 600 and 1000 mesh and polished them with $\mathrm{Al}_{2} \mathrm{O}_{3}(1 \mu \mathrm{m})$ to obtain a smooth surface.

Metallographic investigations were performed using a light microscope (Zeiss Axiotech, Jena, Germany). A DSC-S75 digital still camera (Sony, Tokyo, Japan), switched to full zoom, was employed to take pictures.

Scanning electron microscopy measurements, including EPMA, were carried out on a Cameca SX 100 instrument (Cameca, Paris, France) electron probe using wavelength dispersive spectroscopy (WDS) for quantitative analyses and employing pure $\mathrm{Ni}$, pure $\mathrm{Sn}$ and pure $\mathrm{Ag}$ as standard materials. The measurements were carried out at $15 \mathrm{kV}$ with a beam current of $20 \mathrm{nA}$. Ni $K_{\alpha}, \mathrm{SnL}_{\alpha}$, and $\mathrm{Ag}$ $\mathrm{L}_{\alpha}$ lines were used for quantitative analyses. We used conventional ZAF matrix correction to calculate the compositions from the measured X-ray intensities.

\section{RESULTS AND DISCUSSION}

Results of the phase analysis based on EPMA and XRD data of samples annealed at 200, 450, 700, and $1050^{\circ} \mathrm{C}$ are summarized in Table III. As already outlined by Schmetterer et al., ${ }^{6}$ EPMA measurements in the Ni-Sn system were affected by a systematic shift of the measured compositions towards the Sn-rich side, so the EPMA values had to be corrected accordingly. The same effect was observed in the ternary Ag-Ni-Sn system, too. In the present study the values for the Ni-Sn phases were corrected again by recalculation of the experimentally determined mass percent according to the deviation from the composition (also in mass percent) of a well-established phase boundary. The values obtained were consistent with the data reported by Schmetterer et al. ${ }^{6}$ In Table III, the corrected values are given.

According to the present results, no ternary compounds have been found in the Ag-Ni-Sn system so far; only binary and unary phases exist in this system having very limited or insignificant solubilities of the respective third metal. Solubilities were considered to be significant only if the measured EPMA values were larger than 0.5 at.\%. Furthermore, phase boundaries in the ternary system were determined to be similar to the binary values, when measured within equilibrium samples. This fact is consistent with the insignificant ternary solubilities mentioned above.

As already briefly discussed in the Experimental Section, the Ag-Ni-Sn system is characterized by a large liquid miscibility gap that extends from the binary Ag-Ni system into the ternary up to a $\mathrm{Sn}$ concentration of about 37 at.\%. Because of bulk demixing within all samples in this composition range, as shown in Fig. 4, it was not possible to establish equilibrium in the solid state, even by prolonged annealing at temperatures above $1000^{\circ} \mathrm{C}$. The necessity to use powder methods for sample preparation in this region meant a large number of manipulations and handling steps with each sample; repeated powdering, pressing and annealing was required. As a consequence, some of the samples (e.g., 38) were shifted from their nominal compositions during this lengthy process.

Four isothermal sections at 200,450, 700 and $1050^{\circ} \mathrm{C}$ were established. They were based on the results of the phase analyses (see Table III) and are represented in Figs. 3-6. The course of the liquid phase boundaries was generally derived from the results of thermal analyses. ${ }^{1}$

\section{Phase Equilibria at $1050^{\circ} \mathrm{C}$}

The isothermal section at $1050^{\circ} \mathrm{C}$ is shown in Fig. 3. All samples are partially liquid, and no solid Ag-Sn phases exist at this temperature. The concentrations of the liquid in the three-phase fields could not be fixed experimentally by EPMA. The composition of the liquid phase in the respective three-phase fields in Fig. 3 was chosen to yield a consistent picture with the liquidus projection and the isopleths obtained from thermal analysis. ${ }^{1}$

There is a small solubility of $\mathrm{Ag}$ in (Ni), which is in agreement with the binary Ag-Ni system. All other compounds in the system have no significant solubility at $1050^{\circ} \mathrm{C}$. The phase $\mathrm{Ni}_{3} \mathrm{Sn} \mathrm{HT}$, which cannot be stabilized by quenching of samples annealed at $1050^{\circ} \mathrm{C}$ (see Schmetterer et al. ${ }^{6}$ ), is 


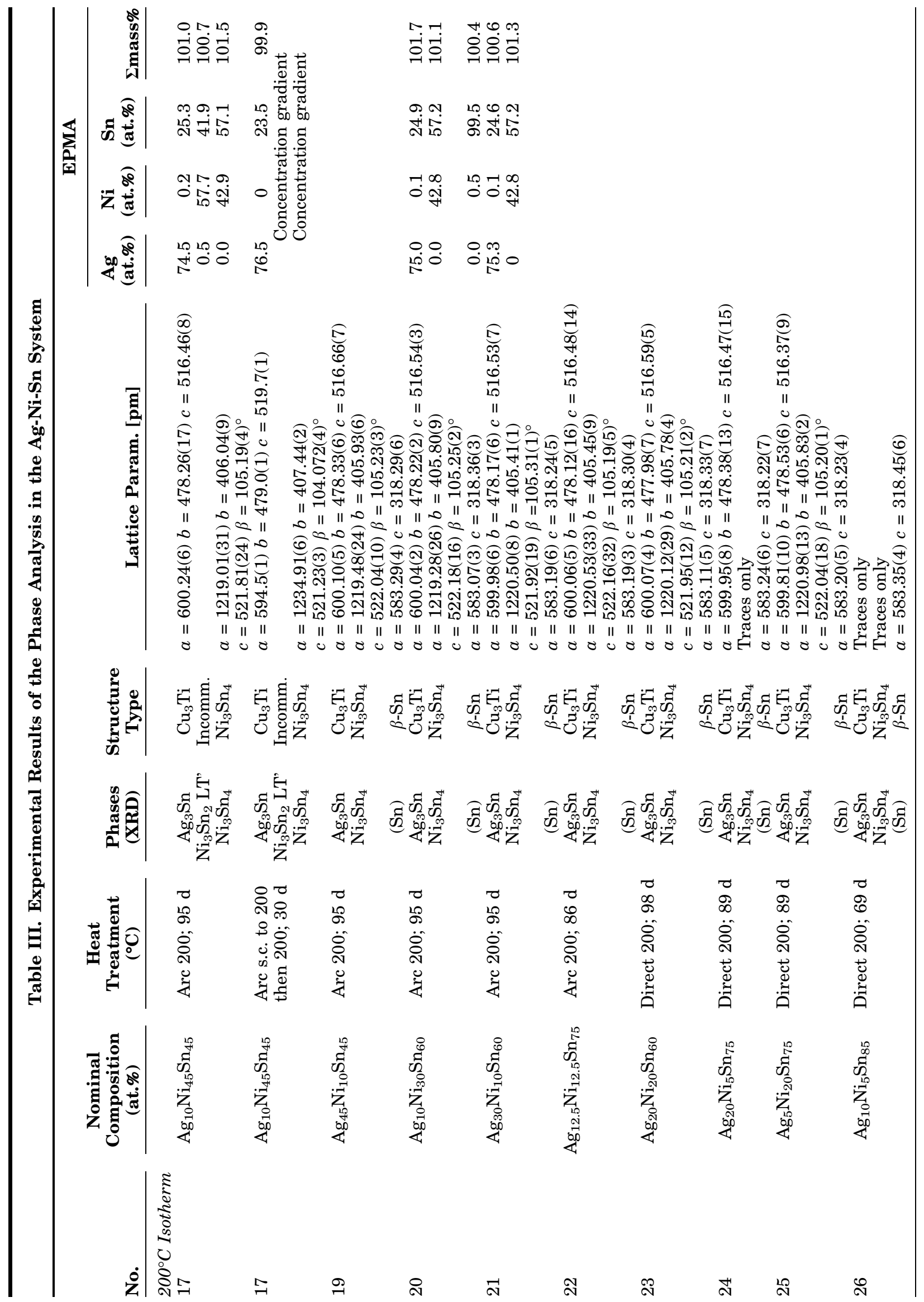




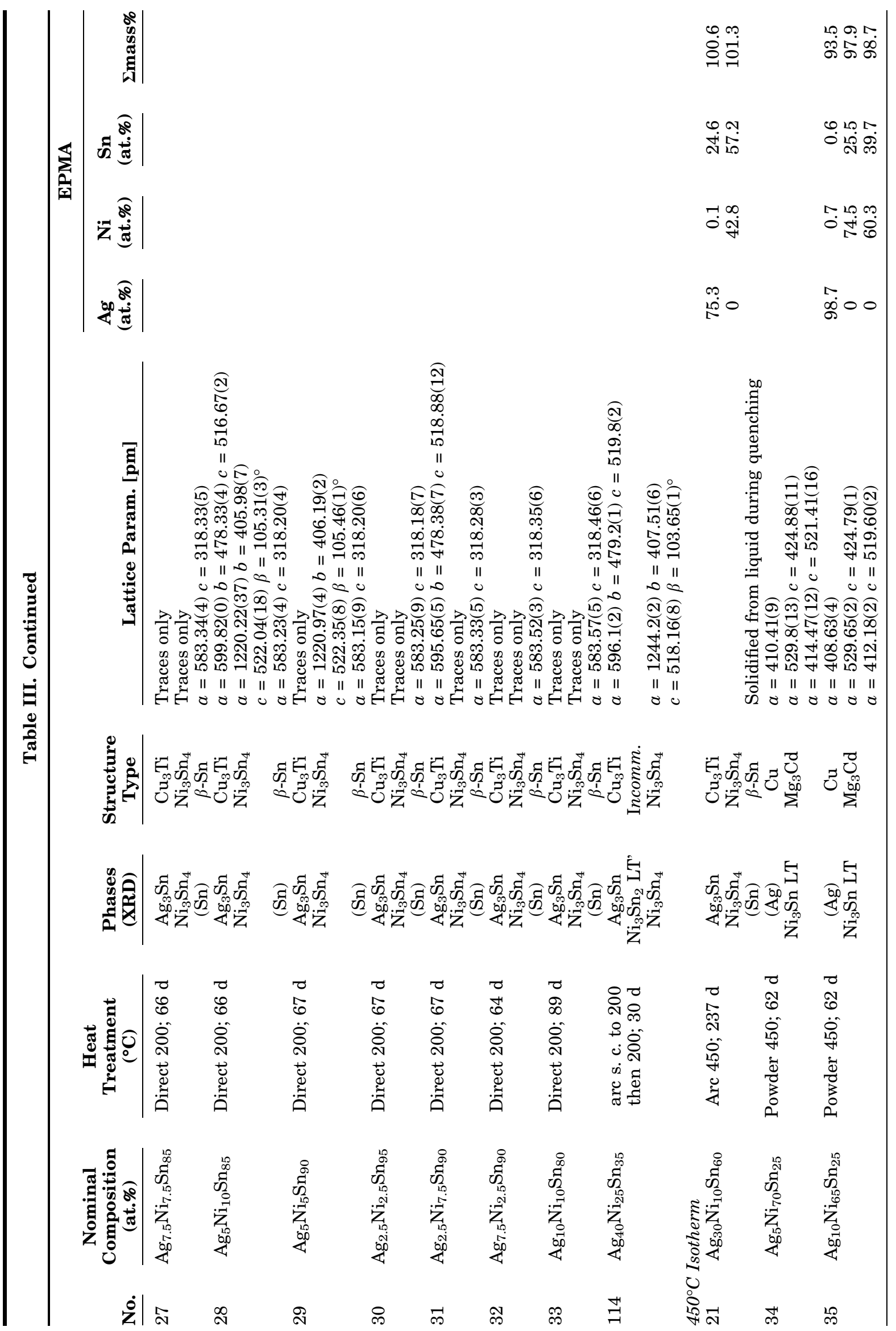




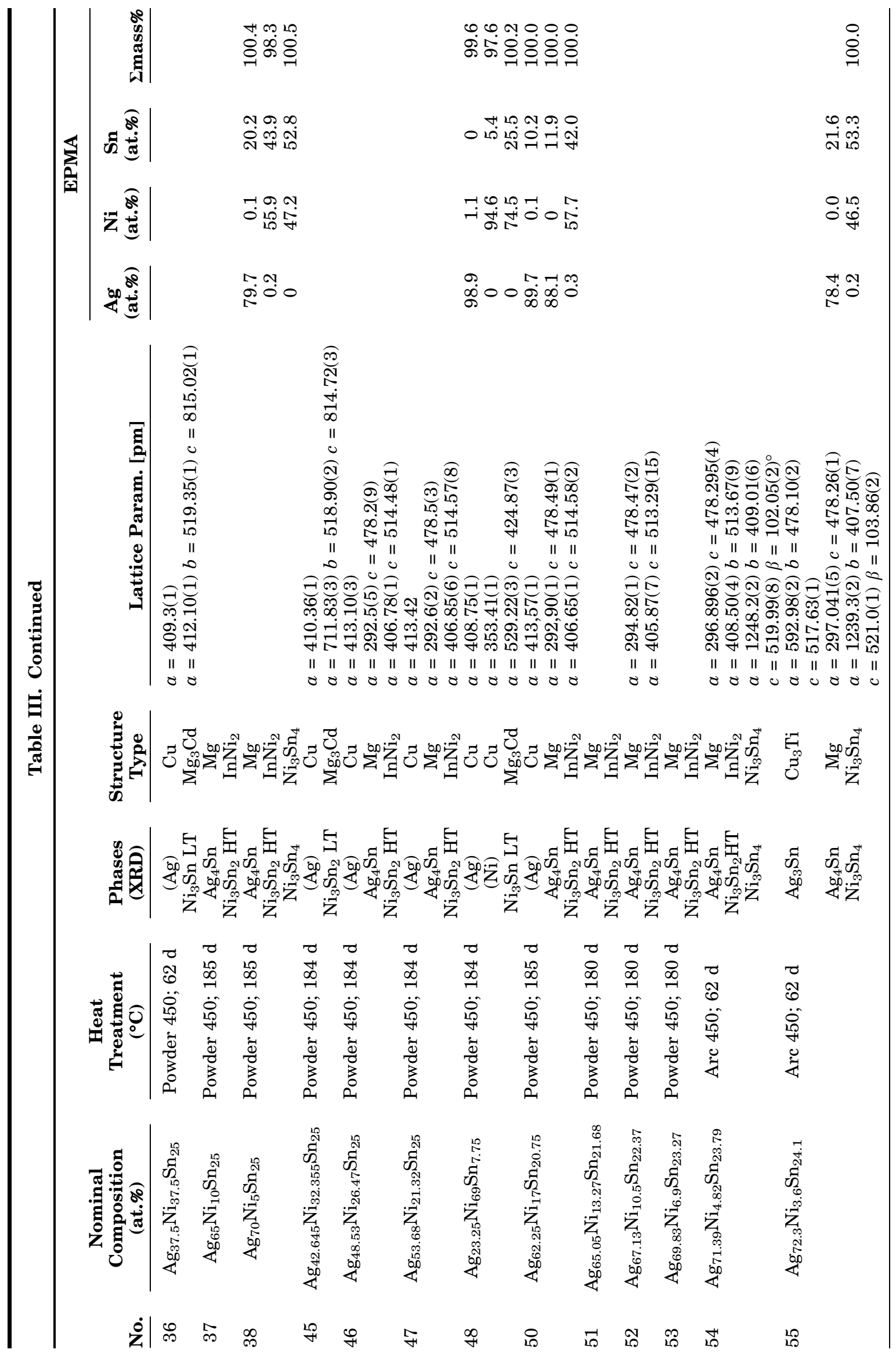




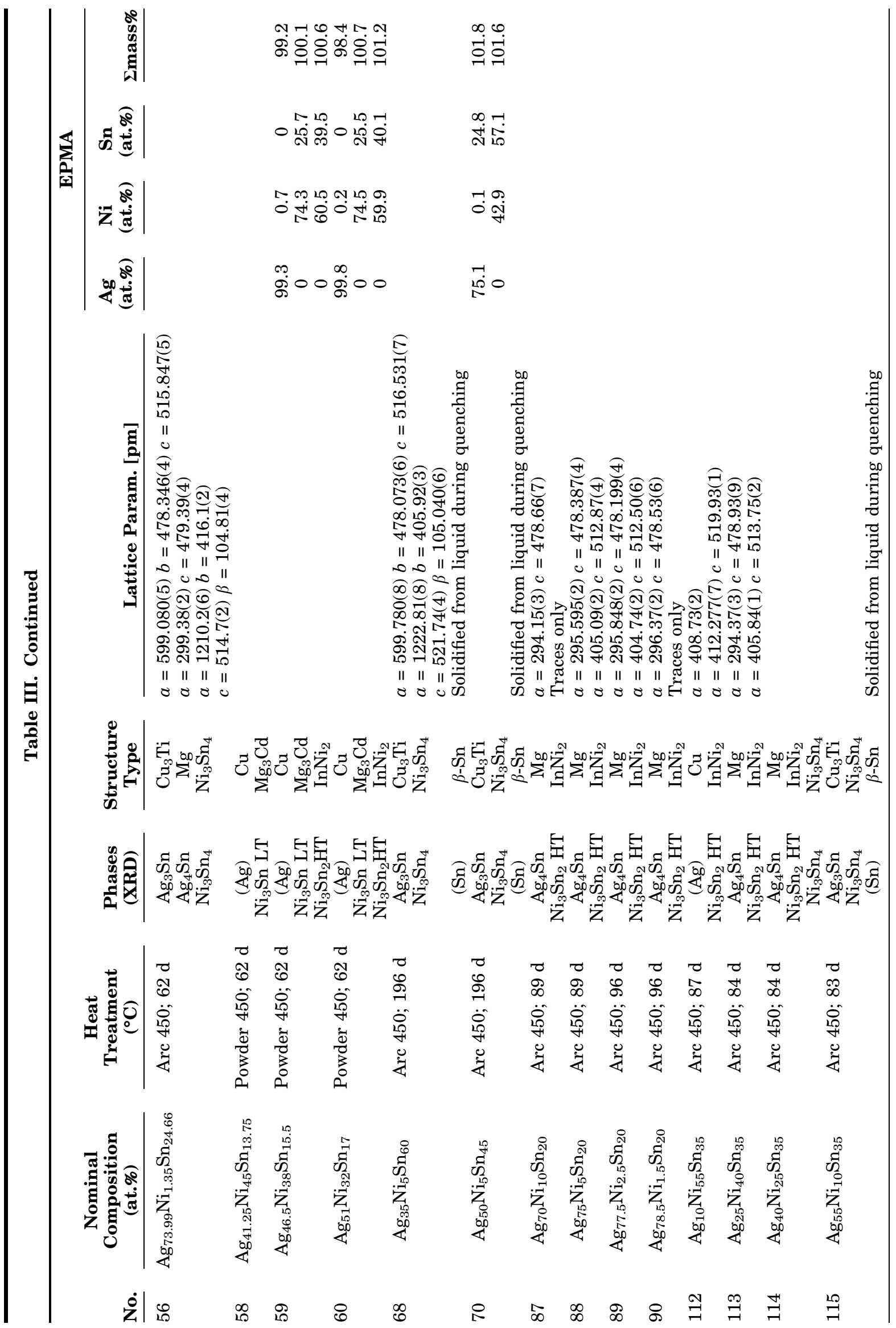




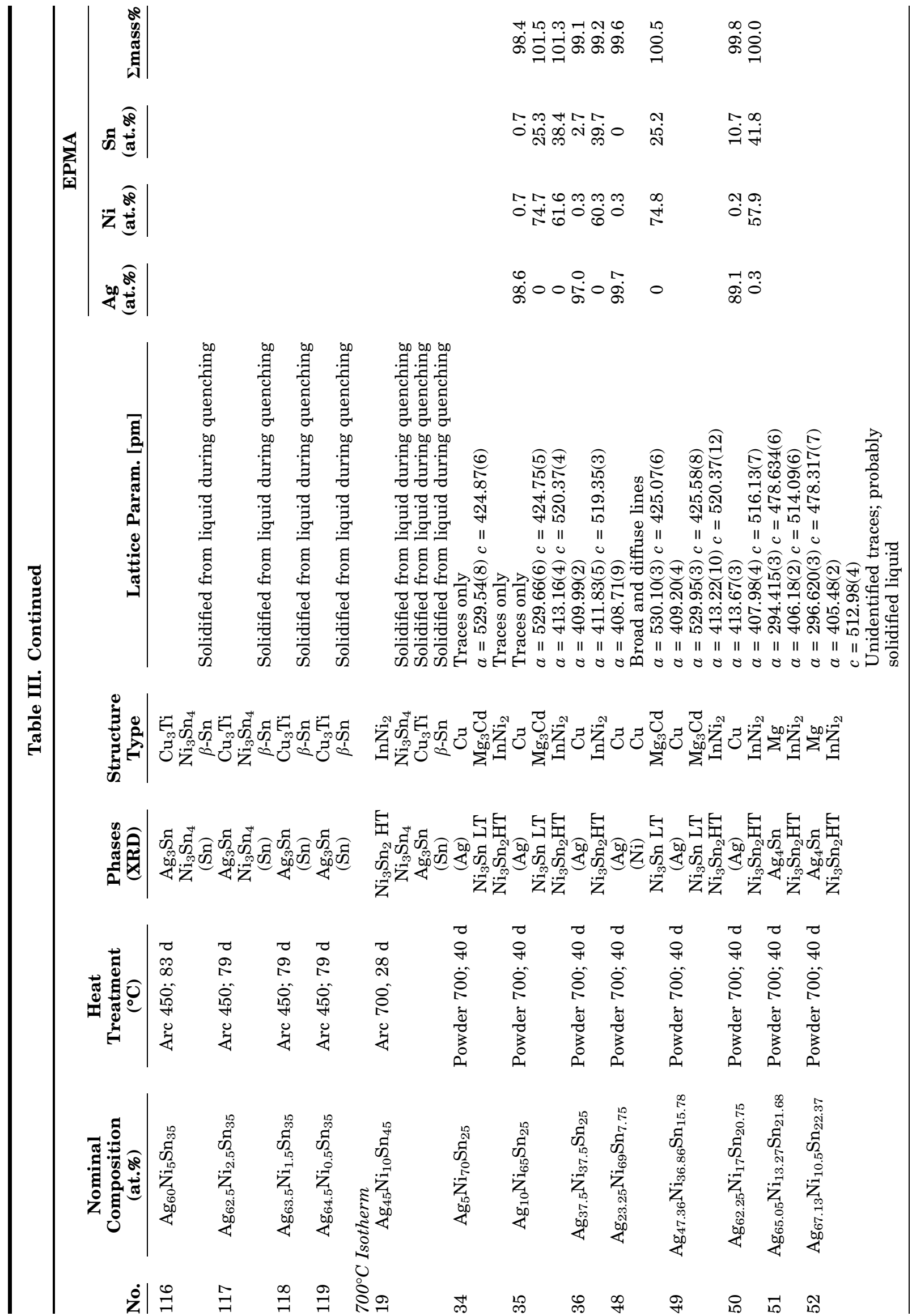




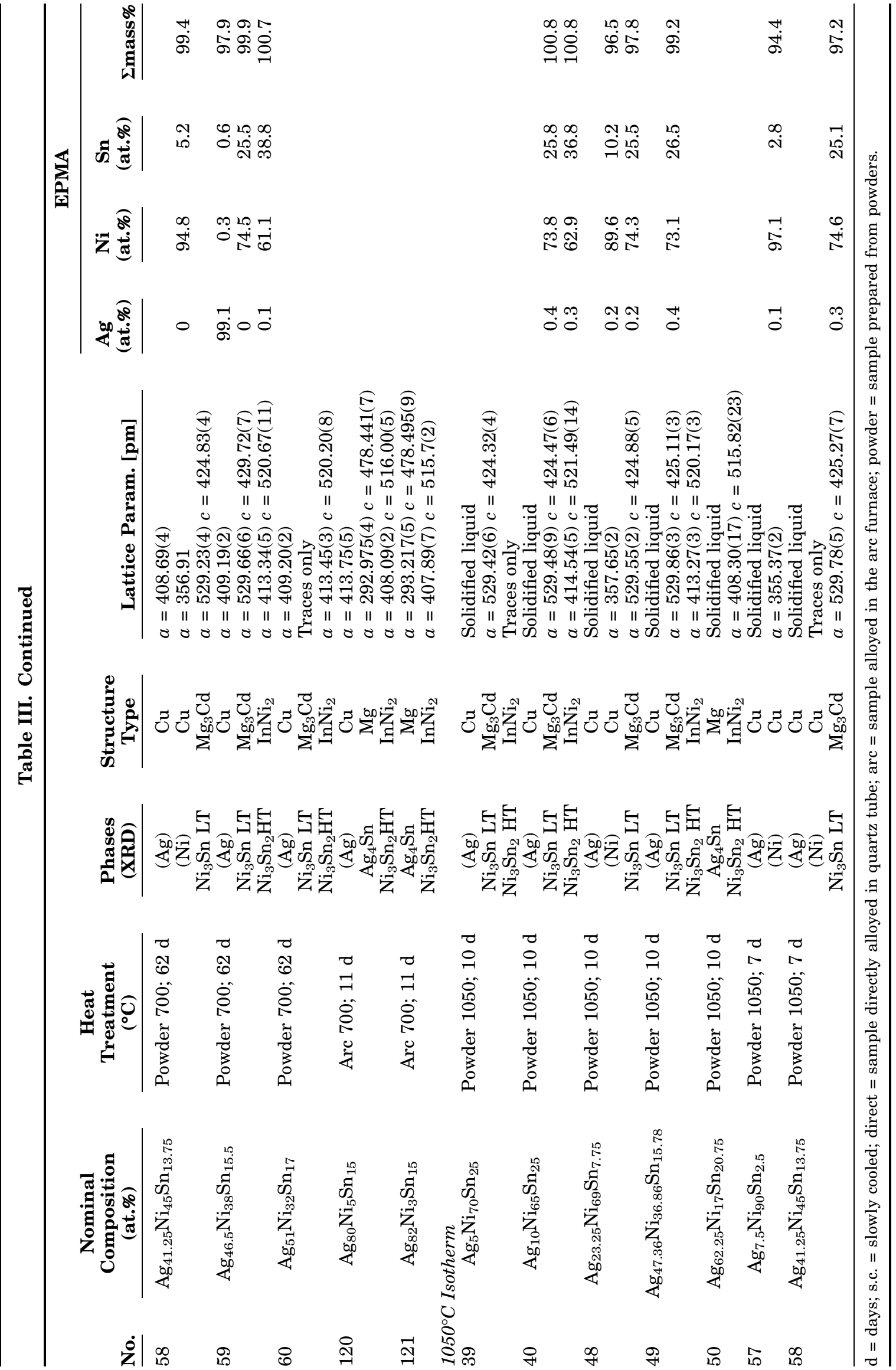




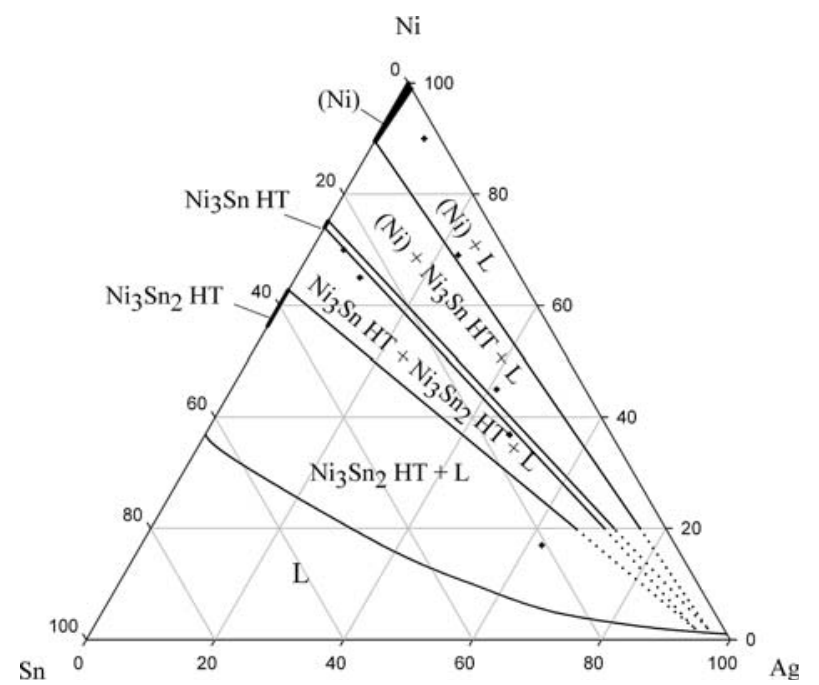

Fig. 3. Ag-Ni-Sn isothermal section at $1050^{\circ} \mathrm{C}$; sample compositions are marked by cross-hairs.

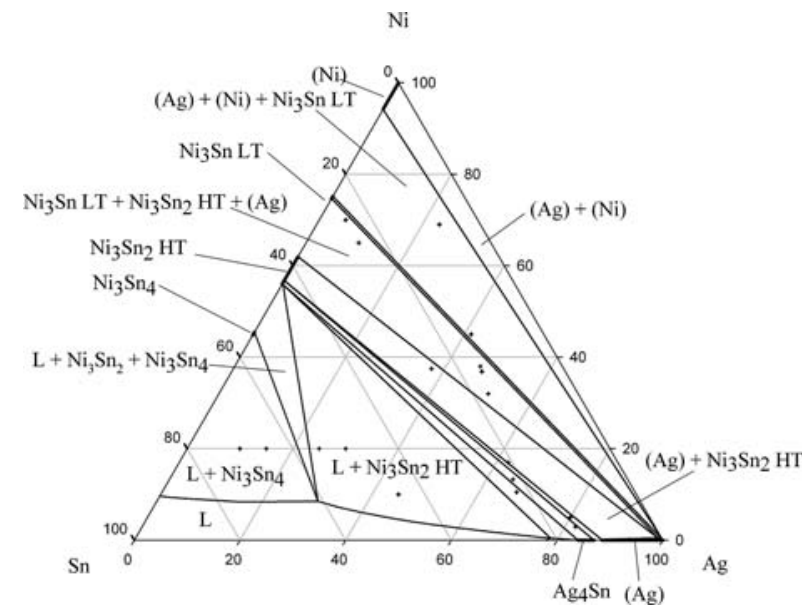

Fig. 4. Ag-Ni-Sn isothermal section at $700^{\circ} \mathrm{C}$; sample compositions are marked by cross-hairs.

presented under the assumption that the transformation into its low temperature modification did not change the phase boundaries.

There was no experimental evidence that the liquid miscibility gap extends down to a temperature of $1050^{\circ} \mathrm{C}$. The shape of the liquidus line that was drawn according to the results from thermal analyses ${ }^{1}$ is consistent with data obtained by Saeed et al. ${ }^{29}$ from calorimetric measurements at $1000^{\circ} \mathrm{C}$.

\section{Phase Equilibria at $7^{\circ}{ }^{\circ} \mathrm{C}$}

At $700^{\circ} \mathrm{C}$ most of the samples of the $(\mathrm{Ag}, \mathrm{Ni})$-rich part were completely solid. Most phase fields shown in the experimental isothermal section at $700^{\circ} \mathrm{C}$ (Fig. 4) could be determined consistently by EPMA and XRD. Ternary solubilities are again insignificant, except for a small solid solubility of about

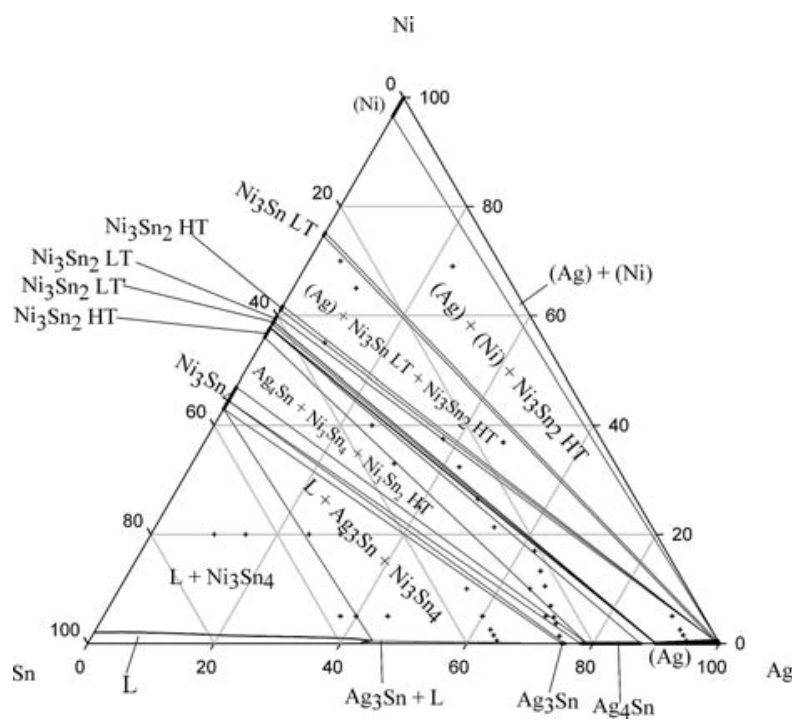

Fig. 5. Ag-Ni-Sn isothermal section at $450^{\circ} \mathrm{C}$; sample compositions are marked by cross-hairs.

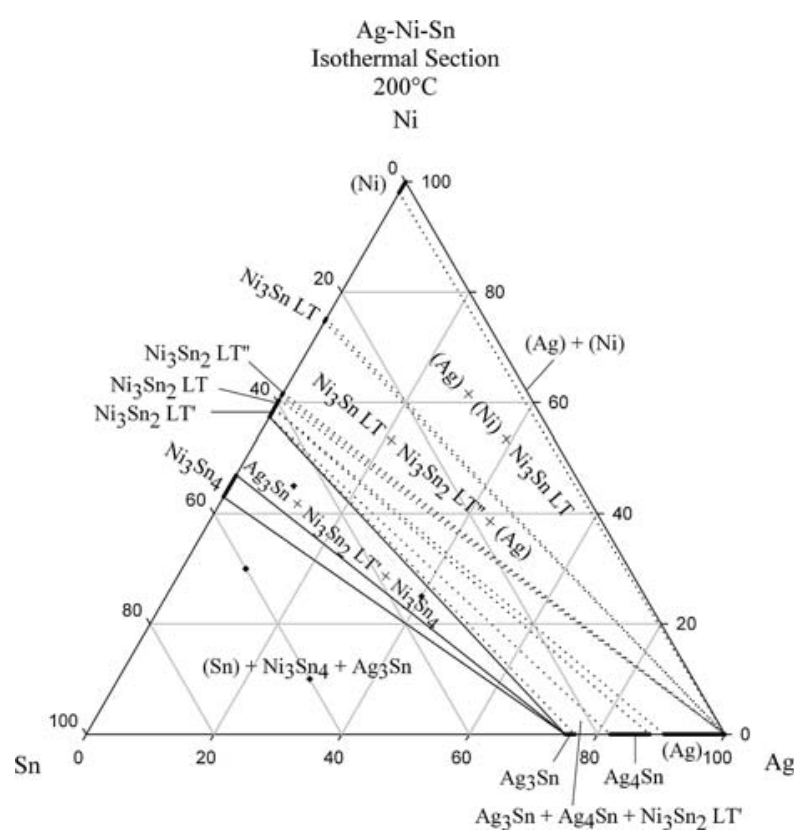

Fig. 6. Only the Sn-rich part has been investigated experimentally. The compositions of samples $17,20,21$, and 114 are marked by cross-hairs.

1 at.\% of $\mathrm{Ni}$ in $(\mathrm{Ag})$. In contrast to the situation at $1050^{\circ} \mathrm{C}$, there is no significant solubility of $\mathrm{Ag}$ in (Ni) at $700^{\circ} \mathrm{C}$ any more. The composition of the liquid in the three-phase field $\left[\mathrm{Ni}_{3} \mathrm{Sn}_{4}+\mathrm{Ni}_{3} \mathrm{Sn}_{2}\right.$ $\mathrm{HT}+\mathrm{L}]$ was estimated from metallography (samples 125-127, see Table IV) and the results from the thermal analysis. ${ }^{1}(\mathrm{Ag})$ and $\mathrm{Ni}_{3} \mathrm{Sn}_{2} \mathrm{HT}$ form a very broad two-phase field. The differing phase triangulation compared to that at $1050^{\circ} \mathrm{C}$, especially the 


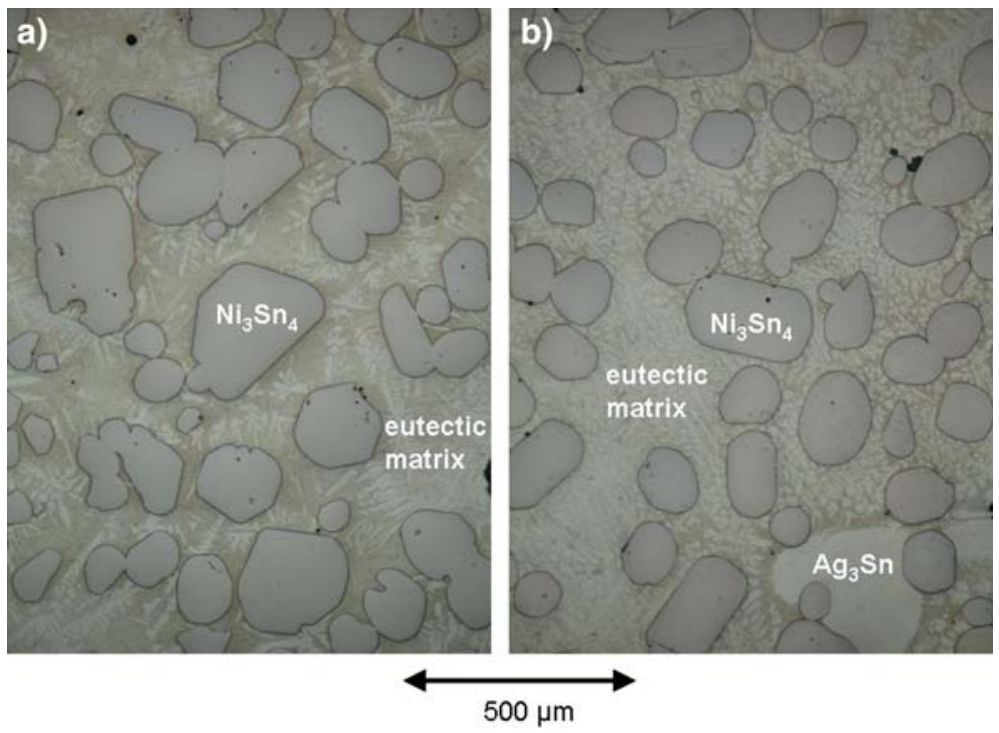

Fig. 7. Metallographic analysis of a series of samples allowed the placement of the boundary between the phase fields $\left[\mathrm{L}+\mathrm{Ag}_{3} \mathrm{Sn}+\mathrm{Ni}_{3} \mathrm{Sn}_{4}\right]$ and $\left[\mathrm{L}+\mathrm{Ni}_{3} \mathrm{Sn}_{4}\right]$. As an example, micrographs of two samples are given: $126\left(\mathrm{Ag}_{15} \mathrm{Ni}_{20} \mathrm{Sn}_{65}\right)$ (a) and $127\left(\mathrm{Ag}_{25} \mathrm{Ni}_{20} \mathrm{Sn}_{55}\right)(\mathrm{b})$. Micrograph (a) shows grains of $\mathrm{Ni}_{3} \mathrm{Sn}_{4}$ and the eutectic matrix. Micrograph (b) shows large grains of $\mathrm{Ag}_{3} \mathrm{Sn}$ and $\mathrm{Ni}_{3} \mathrm{Sn}_{4}$ surrounded by the eutectic matrix (liquid at the annealing temperature).

Table IV. Metallographic Results at $450^{\circ} \mathrm{C}$

\begin{tabular}{|c|c|c|c|}
\hline No. & Nominal Composition (at. \%) & Heat Treatment $\left({ }^{\circ} \mathbf{C}\right)$ & Phases Detected (SEM) \\
\hline \multicolumn{4}{|r|}{ 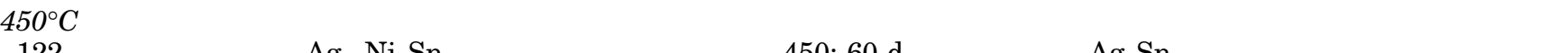 } \\
\hline 122 & $\mathrm{Ag}_{45} \mathrm{Ni}_{5} \mathrm{Sn}_{50}$ & $450 ; 60 \mathrm{~d}$ & $\begin{array}{l}\mathrm{Ag}_{3} \mathrm{Sn} \\
\mathrm{Ni}_{3} \mathrm{Sn}_{4} \\
\text { Eutectic Matrix: } \mathrm{Ag}_{3} \mathrm{Sn}, \mathrm{Ni}_{3} \mathrm{Sn}_{4},(\mathrm{Sn})\end{array}$ \\
\hline 123 & $\mathrm{Ag}_{40} \mathrm{Ni}_{5} \mathrm{Sn}_{55}$ & $450 ; 60 \mathrm{~d}$ & $\begin{array}{l}\mathrm{Ni}_{3} \mathrm{Sn}_{4} \\
\text { Eutectic Matrix: } \mathrm{Ag}_{3} \mathrm{Sn}, \mathrm{Ni}_{3} \mathrm{Sn}_{4},(\mathrm{Sn})\end{array}$ \\
\hline 124 & $\mathrm{Ag}_{37.5} \mathrm{Ni}_{5} \mathrm{Sn}_{57.5}$ & $450 ; 60 \mathrm{~d}$ & $\begin{array}{l}\mathrm{Ni}_{3} \mathrm{Sn}_{4} \\
\text { Eutectic Matrix: } \mathrm{Ag}_{3} \mathrm{Sn}, \mathrm{Ni}_{3} \mathrm{Sn}_{4},(\mathrm{Sn})\end{array}$ \\
\hline 125 & $\mathrm{Ag}_{10} \mathrm{Ni}_{20} \mathrm{Sn}_{70}$ & $450 ; 60 \mathrm{~d}$ & $\begin{array}{l}\mathrm{Ni}_{3} \mathrm{Sn}_{4} \\
\text { Eutectic Matrix: } \mathrm{Ag}_{3} \mathrm{Sn}, \mathrm{Ni}_{3} \mathrm{Sn}_{4},(\mathrm{Sn})\end{array}$ \\
\hline 126 & $\mathrm{Ag}_{15} \mathrm{Ni}_{20} \mathrm{Sn}_{65}$ & $450 ; 60 \mathrm{~d}$ & $\begin{array}{l}\mathrm{Ni}_{3} \mathrm{Sn}_{4} \\
\text { Eutectic Matrix: } \mathrm{Ag}_{3} \mathrm{Sn}, \mathrm{Ni}_{3} \mathrm{Sn}_{4},(\mathrm{Sn})\end{array}$ \\
\hline 127 & $\mathrm{Ag}_{25} \mathrm{Ni}_{20} \mathrm{Sn}_{55}$ & $450 ; 60 \mathrm{~d}$ & $\begin{array}{l}\mathrm{Ag}_{3} \mathrm{Sn} \\
\mathrm{Ni}_{3} \mathrm{Sn}_{4}(\text { small amount }) \\
\text { Eutectic Matrix: } \mathrm{Ag}_{3} \mathrm{Sn}, \mathrm{Ni}_{3} \mathrm{Sn}_{4},(\mathrm{Sn})\end{array}$ \\
\hline 128 & $\mathrm{Ag}_{30} \mathrm{Ni}_{20} \mathrm{Sn}_{50}$ & $450 ; 60 \mathrm{~d}$ & $\begin{array}{l}\mathrm{Ag}_{3} \mathrm{Sn} \\
\mathrm{Ni}_{3} \mathrm{Sn}_{4} \\
\text { Eutectic Matrix: } \mathrm{Ag}_{3} \mathrm{Sn}, \mathrm{Ni}_{3} \mathrm{Sn}_{4},(\mathrm{Sn})\end{array}$ \\
\hline 125 & $\mathrm{Ag}_{10} \mathrm{Ni}_{20} \mathrm{Sn}_{70}$ & $700 ; 60 \mathrm{~d}$ & $\begin{array}{l}\mathrm{Ni}_{3} \mathrm{Sn}_{4} \\
\text { Eutectic Matrix: } \mathrm{Ag}_{3} \mathrm{Sn}, \mathrm{Ni}_{3} \mathrm{Sn}_{4},(\mathrm{Sn})\end{array}$ \\
\hline 126 & $\mathrm{Ag}_{15} \mathrm{Ni}_{20} \mathrm{Sn}_{65}$ & $700 ; 60 \mathrm{~d}$ & $\begin{array}{l}\mathrm{Ni}_{3} \mathrm{Sn}_{4} \\
\text { Eutectic Matrix: } \mathrm{Ag}_{3} \mathrm{Sn}, \mathrm{Ni}_{3} \mathrm{Sn}_{4},(\mathrm{Sn})\end{array}$ \\
\hline 127 & $\mathrm{Ag}_{25} \mathrm{Ni}_{20} \mathrm{Sn}_{55}$ & $700 ; 60 \mathrm{~d}$ & $\begin{array}{l}\mathrm{Ni}_{3} \mathrm{Sn}_{2} \\
\text { Eutectic Matrix: } \mathrm{Ag}_{3} \mathrm{Sn}, \mathrm{Ni}_{3} \mathrm{Sn}_{4},(\mathrm{Sn})\end{array}$ \\
\hline 128 & $\mathrm{Ag}_{30} \mathrm{Ni}_{20} \mathrm{Sn}_{50}$ & $700 ; 60 \mathrm{~d}$ & $\begin{array}{l}\mathrm{Ni}_{3} \mathrm{Sn}_{2} \\
\text { Eutectic Matrix: } \mathrm{Ag}_{3} \mathrm{Sn}, \mathrm{Ni}_{3} \mathrm{Sn}_{4},(\mathrm{Sn})\end{array}$ \\
\hline
\end{tabular}


succession of the phase-fields $\left[(\mathrm{Ag})+\mathrm{Ag}_{4} \mathrm{Sn}+\right.$ $\left.\mathrm{Ni}_{3} \mathrm{Sn}_{2} \mathrm{HT}\right],\left[\mathrm{Ag}_{4} \mathrm{Sn}+\mathrm{Ni}_{3} \mathrm{Sn}_{2} \mathrm{HT}\right]$, and $\left[\mathrm{Ag}_{4} \mathrm{Sn}+\right.$ $\left.\mathrm{Ni}_{3} \mathrm{Sn}_{2} \mathrm{HT}+\mathrm{L}\right]$, is consistent with U-type transition reactions found at intermediate temperatures. ${ }^{1}$

\section{Phase Equilibria at $450^{\circ} \mathrm{C}$}

The phase triangulation at $450^{\circ} \mathrm{C}$, shown in the isothermal section in Fig. 5, is based on experimental data for the entire concentration range. A preliminary version of this section has already been given by Ipser et al. ${ }^{26}$ however, the version presented here is refined in several details due to the investigation of an additional number of samples.

In line with observations at the higher temperatures, no significant ternary solubilities were found, except for a small ternary solubility of $<1$ at. $\% \mathrm{Ni}$ in the (Ag) phase. The phase triangulation was based on the results from EPMA, XRD, and metallography. As the liquidus composition in the phase field $\left[\mathrm{Ag}_{3} \mathrm{Sn}+\mathrm{Ni}_{3} \mathrm{Sn}_{4}+\mathrm{L}\right]$ could not be fixed by EPMA, it was determined from the microstructures of an additional set of samples (122-128, see Table IV) that were partially liquid at $450^{\circ} \mathrm{C}$. Samples $123-$ 126 clearly showed primary crystallization of $\mathrm{Ni}_{3} \mathrm{Sn}_{4}$ and a fine eutectic matrix comprising the phases $\mathrm{Ag}_{3} \mathrm{Sn}, \mathrm{Ni}_{3} \mathrm{Sn}_{4}$ and ( $\mathrm{Sn}$ ) that had solidified from the liquid during quenching, see, e.g., sample 126 in Fig. 7a. The microstructure therefore suggests the presence of the two phases $\mathrm{Ni}_{3} \mathrm{Sn}_{4}+\mathrm{L}$ at the annealing temperature. In the remaining samples 122,127 , and 128, the microstructure suggests the presence of three phases $\left(\mathrm{Ag}_{3} \mathrm{Sn}+\mathrm{Ni}_{3} \mathrm{Sn}_{4}+\mathrm{L}\right)$ at $450^{\circ} \mathrm{C}$. Thus, the corresponding boundary of the three-phase field $\left[\mathrm{Ag}_{3} \mathrm{Sn}+\mathrm{Ni}_{3} \mathrm{Sn}_{4}+\mathrm{L}\right]$ was placed close to sample 127, where only a rather small amount of $\mathrm{Ag}_{3} \mathrm{Sn}$ grains was found; see sample 127 in Fig. $7 \mathrm{~b}$.

The phase triangulation in the area of $\mathrm{Ag}_{4} \mathrm{Sn}$, $\mathrm{Ag}_{3} \mathrm{Sn}$, and $\mathrm{Ni}_{3} \mathrm{Sn}_{4}$ is based on the XRD and EPMA results from samples $37,38,54-56$. In the case of samples 38 and 55, we found indications of a shift in the nominal composition. Repeated powdering during sample preparation (38) and stress annealing of the powders used for XRD (55) may be the reason. Despite these experimental shortcomings, a consistent solution for this area could be developed.

The rather complicated phase triangulation around the $\mathrm{Ni}_{3} \mathrm{Sn}_{2}$ phases (the section at $450^{\circ} \mathrm{C}$ lies within the binary $\mathrm{Ni}_{3} \mathrm{Sn}_{2}$ phase transition ${ }^{7}$ ) was based on the results from XRD and some EPMA measurements. As the differences in composition among the various $\mathrm{Ni}_{3} \mathrm{Sn}_{2}$ phases were very small, EPMA alone did not yield reliable results in this area. Owing to the complexity of this area and the complications just mentioned, the position of some corners of certain phase fields had been left out in the earlier work of Ipser et al. ${ }^{26}$

The investigation of additional samples allowed the evaluation presented in Fig. 5: there is a broad two-phase field $\left[\mathrm{Ag}_{4} \mathrm{Sn}+\mathrm{Ni}_{3} \mathrm{Sn}_{2} \mathrm{HT}\right]$ and a narrow three-phase field $\left[\mathrm{Ag}_{4} \mathrm{Sn}+\mathrm{Ag}+\mathrm{Ni}_{3} \mathrm{Sn}_{2} \mathrm{HT}\right]$, both determined from XRD. Further phase fields, $\left[\begin{array}{lll}\mathrm{Ni}_{3} \mathrm{Sn}_{2} & \mathrm{HT}+(\mathrm{Ag})\end{array}\right], \quad\left[\mathrm{Ni}_{3} \mathrm{Sn}_{2} \mathrm{HT}+\mathrm{Ni}_{3} \mathrm{Sn}_{2} \mathrm{LT}^{\prime}+\right.$ $(\mathrm{Ag})],\left[\mathrm{Ni}_{3} \mathrm{Sn}_{2} \mathrm{LT}^{\prime}+(\mathrm{Ag})\right]$, and $\left[\mathrm{Ni}_{3} \mathrm{Sn}_{2} \mathrm{LT}^{\prime}+\mathrm{Ni}_{3} \mathrm{Sn}_{2}\right.$ $\mathrm{LT}+(\mathrm{Ag})]$, could not be determined experimentally, but they are a consequence of the binary phase relations and other experimental results in the ternary system.

\section{Phase Equilibria at $200^{\circ} \mathrm{C}$}

In terms of soldering, the isothermal section at $200^{\circ} \mathrm{C}$ (Fig. 6) is usually considered to be the most important one of the set presented here. Nevertheless, the complete study of an alloy system is preferable, even if the technological interest may be focused on certain temperature and/or concentration ranges. Only then will it be possible to gain a consistent description, especially if CALPHAD optimization and modeling are to be performed. Furthermore, for solder systems, interfacial diffusion and reactions are highly important which can be influenced by phase relations in the entire concentration range.

In our study of the Ag-Ni-Sn system, this became clear during experimental work for the isothermal section at $200^{\circ} \mathrm{C}$. First of all, only samples with Sn-content above app. 35 at.\% were prepared, as only those have a chance to reach an equilibrium state in a reasonable time (roughly 3 months). In fact, it turned out that samples placed around 35 at.\% Sn were already at the margin of the experimentally accessible part of this isothermal section. Even after prolonged annealing at $200^{\circ} \mathrm{C}$, the correct phase equilibria have not always been established, probably due to insufficient diffusion at this temperature far below the liquidus.

Thus, only the Sn-rich part of this isothermal section (Fig. 6) was determined experimentally. Two three-phase fields, $\left[(\mathrm{Sn})+\mathrm{Ni}_{3} \mathrm{Sn}_{4}+\mathrm{Ag}_{3} \mathrm{Sn}\right]$ and $\left[\mathrm{Ni}_{3} \mathrm{Sn}_{4}+\mathrm{Ni}_{3} \mathrm{Sn}_{2} \mathrm{LT}^{\prime}+\mathrm{Ag}_{3} \mathrm{Sn}\right]$, separated by the two-phase field $\left[\mathrm{Ni}_{3} \mathrm{Sn}_{4}+\mathrm{Ag}_{3} \mathrm{Sn}\right]$ are based on experimental results. In samples $17\left(\mathrm{Ag}_{10} \mathrm{Ni}_{45} \mathrm{Sn}_{45}\right)$ and $114\left(\mathrm{Ag}_{40} \mathrm{Ni}_{25} \mathrm{Sn}_{35}\right)$, however, both within the three-phase field $\left[\mathrm{Ni}_{3} \mathrm{Sn}_{4}+\mathrm{Ni}_{3} \mathrm{Sn}_{2} \mathrm{LT}^{\prime}+\mathrm{Ag}_{3} \mathrm{Sn}\right]$, it turned out that even pre-annealing at $550^{\circ} \mathrm{C}$ ( 2 days), followed by slow cooling $(0.25 \mathrm{~K} / \mathrm{min})$ to $200{ }^{\circ} \mathrm{C}$ and further annealing at this temperature, did not yield the full thermodynamic equilibrium. While XRD showed that the expected phases had formed, EPMA revealed concentration gradients in $\mathrm{Ni}_{3} \mathrm{Sn}_{2} \mathrm{LT}^{\prime}$ and $\mathrm{Ni}_{3} \mathrm{Sn}_{4}$ indicating non-equilibrium. Due to the insignificant solubility of Ag in these two phases, the phase field boundaries were drawn according to the values from the binary Ni-Sn system (compare Schmetterer et al. ${ }^{6}$ ).

A comparison of this area at $200^{\circ} \mathrm{C}$ with the isothermal section at $450^{\circ} \mathrm{C}$ reveals a change in the phase triangulation that is reflected by the threephase fields $\left[\mathrm{Ag}_{3} \mathrm{Sn}+\mathrm{Ni}_{3} \mathrm{Sn}_{4}+\mathrm{Ni}_{3} \mathrm{Sn}_{2} \mathrm{LT}^{\prime}\right]$ at $200^{\circ} \mathrm{C}$ and $\left[\mathrm{Ag}_{3} \mathrm{Sn}+\mathrm{Ag}_{4} \mathrm{Sn}+\mathrm{Ni}_{3} \mathrm{Sn}_{4}\right]$ at $450^{\circ} \mathrm{C}$. This change suggests the existence of a ternary type II (U) reaction involving four solid phases (probably 
$\left.\mathrm{Ag}_{4} \mathrm{Sn}+\mathrm{Ni}_{3} \mathrm{Sn}_{4} \Rightarrow \mathrm{Ag}_{3} \mathrm{Sn}+\mathrm{Ni}_{3} \mathrm{Sn}_{2} \mathrm{LT}^{\prime}\right)$ in addition to a reaction related to the $\mathrm{Ni}_{3} \mathrm{Sn}_{2}$ phase transition $\left(\mathrm{HT} \rightarrow \mathrm{LT}^{\prime}\right)$.

The phase triangulation in the Sn-rich part is in good agreement with the calculations of Ghosh ${ }^{23}$ at $230^{\circ} \mathrm{C}$ and $\mathrm{Hsu}$ and $\mathrm{Chen}^{24}$ at $240^{\circ} \mathrm{C}$, and with the experimental work of the latter authors, except for the wider homogeneity range of $\mathrm{Ni}_{3} \mathrm{Sn}_{4}$ in our work.

The phase equilibria in the $(\mathrm{Ag}, \mathrm{Ni})$-rich part of Fig. 6 are estimated from binary data and from the results of phase analysis at higher temperature; they are, therefore, represented by dashed lines. For example, ternary solubilities of $\mathrm{Ni}$ in (Ag) at 450 and $700^{\circ} \mathrm{C}$ have already been shown to be smaller than 1 at.\%, while $\mathrm{Hsu}$ and $\mathrm{Chen}^{24}$ reported a solubility of about 3 at. $\%$ at $240^{\circ} \mathrm{C}$ in their experimental work. As an increase in solubility with decreasing temperature is rather unlikely, a negligible solubility of $\mathrm{Ni}$ in the (Ag)-phase is shown in Fig. 6. Phase equilibrium was probably not established in their case, due to slow diffusion in a temperature range far below the melting point, regarding the difficulties in establishing equilibrium in more Sn-rich and thus lower melting parts of the system. However, it is surprising that $\mathrm{Hsu}$ and $\mathrm{Chen}^{24}$ investigated samples in the $(\mathrm{Ag}, \mathrm{Ni})$-rich part which had been prepared directly from the melt but did not mention any problems with non-equilibrium and/or bulk demixing of the liquid phase, as was observed here.

In Fig. 6, a reasonable suggestion is also made for the situation around the three $\mathrm{Ni}_{3} \mathrm{Sn}_{2}$ LT-phases, again developed from the situation in the binary boundary systems and consistent with phase equilibria at higher temperature. These phase equilibria have to be far more complicated than hitherto reported in the literature ${ }^{23,24}$, because of the existence of the $\mathrm{Ni}_{3} \mathrm{Sn}_{2} \mathrm{LT}^{\prime}$ - and $\mathrm{LT}^{\prime \prime}$-phases.

\section{CONCLUSION}

A set of consistent isothermal sections at 200, 450, 700 , and $1050^{\circ} \mathrm{C}$ was presented for the ternary Ag-Ni-Sn system. Experimental difficulties due to liquid demixing were highlighted, and solutions were presented that allowed us to obtain equilibrium samples. Together with the results from thermal analyses ${ }^{1}$, these data will allow a full understanding of the phase equilibria in this system that is of high technological importance.

\section{ACKNOWLEDGEMENTS}

This research is a contribution to the European COST Action 531. Financial support from the Austrian Science Foundation (FWF) under Project
No. P-16495-N11 is gratefully acknowledged. The authors also want to thank Prof. Harald Schmidt, Department for Physical Chemistry of the University of Vienna, for his assistance with metallographic investigations.

\section{REFERENCES}

1. C. Schmetterer, H. Flandorfer, and H. Ipser, accepted for publication in Acta mat.

2. M. Singleton and P. Nash, Bull. Alloy Phase Diag. 8, 119 (1987).

3. T.B. Massalski, H. Okamoto, P.R. Subramanian, and L. Kacprzak, Binary Alloy Phase Diagrams. ASM International (1996).

4. C. Colinet and A. Pasturel, Z. Metallkd. 89, 863 (1998).

5. I. Karakaya and W.T. Thompson, Bull. Alloy Phase Diag. 8, 340 (1987).

6. C. Schmetterer, H. Flandorfer, K.W. Richter, U. Saeed, M. Kauffman, P. Roussel, and H. Ipser, Intermetallics 15(7), 869 (2007).

7. P. Nash and A. Nash, Bull. Alloy Phase Diag. 6, 350 (1985).

8. G. Ghosh, Metall. Mater. Trans. A 30, 1481 (1999).

9. H.S. Liu, J. Wang, and Z.P. Jin, CALPHAD: Comput. Coupling Phase Diagrams Thermochem. 28, 363 (2005).

10. A. Havlicek (Ph.D. Thesis, University of Vienna, 1991).

11. W. Mikulas and L. Thomassen, Trans. AIME, Inst. Metal. Div. 124, 111 (1937).

12. K. Schubert, W. Burkhardt, P. Esslinger, E. Günzel, H.G. Meissner, W. Schütt, J. Wegst, and M. Wilkens, Naturwissenschaften 43, 248 (1956).

13. A. Leineweber, M. Ellner, and E.J. Mittemeijer, J. Solid State Chem. 159, 191 (2001).

14. A. Leineweber, O. Oeckler, and U. Zachwieja, J. Solid State Chem. 177, 936 (2004).

15. A. Leineweber, J. Solid State Chem. 177, 1197 (2004).

16. A. Leineweber, E.J. Mittemeijer, M. Knapp, and C. Baehtz, Mater. Sci. Forum 443-444, 247 (2004).

17. E. Fetz and E.R. Jette, J. Chem. Phys. 4, 537 (1936).

18. E. Fetz and E.R. Jette, Trans. AIME 124, 133 (1937).

19. O. Nial, Svensk Kemisk Tidskrift 59-60, 172 (1947-1948).

20. F. Lihl and H. Kirnbauer, Monatsh. Chem. 86, 745 (1955).

21. F. Lihl and H. Kirnbauer, Z. Metallkd. 46, 438 (1955).

22. M.K. Bhargava and K. Schubert, J. Less-Common Met. 33, 181 (1973).

23. G. Ghosh, J. Electron. Mater. 29, 1182 (2000).

24. Hs.-F. Hsu and S.-W. Chen, Acta Mater. 52, 2541 (2004).

25. S.-W. Chen, Hs.-F. Hsu, and Ch.-W. Lin, J. Mater. Res. 19, 2262 (2004).

26. H. Ipser, H. Flandorfer, Ch. Luef, C. Schmetterer, and U. Saeed, J. Mater. Sci.: Mater. Electron. 1-3, 3 (2007).

27. STRUKTUR-PC-program package (Wacha W. Diploma Thesis, Vienna University of Technology, 1989).

28. P. Villars and L.D. Calvert, Pearson's Handbook of Crystallographic Data for Intermetallic Phases. ASM International (1991).

29. U. Saeed, H. Flandorfer, and H. Ipser, J. Mater. Res. 21, 1294 (2006). 